\title{
Impact of No-Tillage and Conventional Tillage Systems on Soil Microbial Communities
}

\author{
Reji P. Mathew, ${ }^{1}$ Yucheng Feng, ${ }^{1}$ Leonard Githinji, ${ }^{2}$ \\ Ramble Ankumah, ${ }^{2}$ and Kipling S. Balkcom ${ }^{3}$ \\ ${ }^{1}$ Department of Agronomy and Soils, Auburn University, Auburn, AL 36849, USA \\ ${ }^{2}$ Department of Agricultural and Environmental Sciences, Tuskegee University, Tuskegee, AL 36088, USA \\ ${ }^{3}$ USDA-ARS, Auburn, AL 36849, USA \\ Correspondence should be addressed to Yucheng Feng, yfeng@auburn.edu \\ Received 6 December 2011; Revised 4 April 2012; Accepted 5 April 2012 \\ Academic Editor: Philip White
}

Copyright () 2012 Reji P. Mathew et al. This is an open access article distributed under the Creative Commons Attribution License, which permits unrestricted use, distribution, and reproduction in any medium, provided the original work is properly cited.

\begin{abstract}
Soil management practices influence soil physical and chemical characteristics and bring about changes in the soil microbial community structure and function. In this study, the effects of long-term conventional and no-tillage practices on microbial community structure, enzyme activities, and selected physicochemical properties were determined in a continuous corn system on a Decatur silt loam soil. The long-term no-tillage treatment resulted in higher soil carbon and nitrogen contents, viable microbial biomass, and phosphatase activities at the $0-5 \mathrm{~cm}$ depth than the conventional tillage treatment. Soil microbial community structure assessed using phospholipid fatty acid (PLFA) analysis and automated ribosomal intergenic spacer analysis (ARISA) varied by tillage practice and soil depth. The abundance of PLFAs indicative of fungi, bacteria, arbuscular mycorrhizal fungi, and actinobacteria was consistently higher in the no-till surface soil. Results of principal components analysis based on soil physicochemical and enzyme variables were in agreement with those based on PLFA and ARISA profiles. Soil organic carbon was positively correlated with most of the PLFA biomarkers. These results indicate that tillage practice and soil depth were two important factors affecting soil microbial community structure and activity, and conservation tillage practices improve both physicochemical and microbiological properties of soil.
\end{abstract}

\section{Introduction}

Tillage systems influence physical, chemical, and biological properties of soil and have a major impact on soil productivity and sustainability. Conventional tillage practices may adversely affect long-term soil productivity due to erosion and loss of organic matter in soils. Sustainable soil management can be practiced through conservation tillage (including no-tillage), high crop residue return, and crop rotation [1]. Studies conducted under a wide range of climatic conditions, soil types, and crop rotation systems showed that soils under no-tillage and reduced tillage have significantly higher soil organic matter contents compared with conventionally tilled soils [2].

Conservation tillage is defined as a tillage system in which at least $30 \%$ of crop residues are left in the field and is an important conservation practice to reduce soil erosion [3]. The advantages of conservation tillage practices over conventional tillage include (1) reducing cultivation cost; (2) allowing crop residues to act as an insulator and reducing soil temperature fluctuation; (3) building up soil organic matter; (4) conserving soil moisture $[4,5]$.

Different tillage practices cause changes in soil physical properties, such as bulk density [6], water holding capacity [7], pore size distribution [8], and aggregation [9]. Stratification of soil organic matter and differences in nutrient distribution have also been observed in long-term conservation tillage systems $[10,11]$. Thus, altered soil physical and chemical conditions under conservation tillage create significantly different habitats for microorganisms and result in shifts of soil microbial community structure [10-13]. Conventional tillage can lead to soil microbial communities 
dominated by aerobic microorganisms, while conservation tillage practices increase microbial population and activity [11] as well as microbial biomass $[10,14]$.

Several studies have examined the effects of tillage practices on soil microbial communities in different cropping systems. In a long-term continuous cotton system, the tillage treatment effect varied by soil depth and over time; the impact of treatments was more pronounced during the fallow period and early in the growing season [12]. Although fungal dominance is commonly assumed in notill soils, the relative abundance of fungi over bacteria is not consistently greater in the Northern Great Plain soils under long-term no-till practices compared with intensive tillage [13]. Ibekwe et al. [15] used biochemical- (i.e., PLFA) and nucleic-acid-based approaches to study the effect of tillage on soil microbial communities in four eastern Washington State soils. PLFA and denaturing gradient gel electrophoresis (DGGE) analyses showed a common pattern of clustering from the four soils and revealed that soil microbial communities respond more to soil management than annual precipitation.

Various culture-independent methods are available for characterizing soil microbial communities; these methods vary in their sensitivity for detecting microbial community changes. Polyphasic approaches are often used to study soil microbial communities due to the extraordinary magnitude of community size and diversity. PLFAs are a major constituent of cell membranes and have been used to identify individual species of bacteria and fungi. Since they are degraded rapidly upon cell death, PLFAs can be used to characterize living microbial biomass. PLFA analysis also provides insights into the broad scale structure of both bacteria and eukaryotic microorganisms [16]. The automated ribosomal analysis (ARISA) is a nucleic-acid-based method, which has a finer resolution for bacterial and fungal communities. This method involves polymerase chain reaction (PCR) amplification of the intergenic region between the small and large subunit ribosomal RNA genes [17]. Since the intergenic region exhibits considerable heterogeneity in both length and nucleotide sequence, ARISA has been used to provide rapid estimation of microbial diversity and community composition.

Soil enzymes play key biochemical functions in the decomposition of organic matter in the soil $[18,19]$. They are process level indicators, which reflect past soil biological activity as influenced by soil management. Phosphatases are a broad group of enzymes that are capable of catalyzing hydrolysis of esters and anhydrides of phosphoric acid and have been reported to be good indicators of soil fertility $[20,21]$. Phosphatases play key roles in phosphorus cycling, including degradation of phospholipids.

Conservation tillage techniques are widely used in the southeastern United States to conserve soil moisture, nutrients, and structure, providing habitats and substrates for biota, especially microorganisms, which are responsible for mineralization of soil nutrients. In this study, the effects of conventional and no-tillage practices on soil microbial communities were investigated in a continuous corn production system by determining microbial community structure using PLFA analysis and ARISA as well as microbial activities as indicated by soil phosphatases. The central hypothesis was that long-term use of no-tillage practices would cause shifts in soil microbial community structure relative to conventional tillage practices.

\section{Materials and Methods}

2.1. Study Site and Soil Sampling. The study site was located at the Tennessee Valley Research and Extension Center in Belle Mina, Alabama, USA. The soil type was a Decatur silt loam (Fine, kaolinitic, thermic Rhodic Paleudults). The field experiment was arranged in a randomized complete block factorial design of four replications with tillage being the main factor. The no-tillage plots were established in 1990 and conventionally tilled plots in 1994 from previously established no-till plots. Conventional tillage involved disking and chisel plowing in the fall followed by disking and field cultivating in the spring. Cotton was planted at the study site until 2003 and corn from 2004. Winter rye was seeded in the fall in no-tillage plots and terminated before spring planting with glyphosate application. A detailed description on the history of the field experiment can be found in Schwab et al. [4]. Soil sampling was performed in April of 2008 prior to planting to minimize the effect of plant growth on microbial communities in order to observe the tillage treatment effect. Soil cores (40 to 45 cores) were collected using tube samplers $(2.5 \mathrm{~cm}$ in diameter) from randomly selected locations in each plot. Soil cores were separated into two depths $(0-5$ and $5-15 \mathrm{~cm}$ ) in the field, composited by depth and thoroughly mixed. Field-moist samples were transported to the laboratory on ice and then passed through a $4 \mathrm{~mm}$ sieve within 24 hours. Three additional intact soil cores were collected from each plot for bulk density determination at two depths.

\subsection{Characterization of Soil Physical and Chemical Properties.} Subsamples from each of the 16 composite samples were taken for gravimetric moisture content determination and chemical analysis after air drying. Total carbon and nitrogen were analyzed using a TruSpec CN analyzer (Leco Corp., St. Joseph, MI, USA). Since there is no appreciable carbonate carbon in this inherently acid soil, the total carbon content is equivalent to the soil organic carbon content. Soil $\mathrm{pH}$ was measured using $1: 1$ soil/water and $1: 2$ soil/ $0.01 \mathrm{M} \mathrm{CaCl}_{2}$ suspensions. Bulk density was determined by measuring the moisture loss from intact soil cores of a known volume after drying at $105^{\circ} \mathrm{C}$ for 24 hours.

2.3. Soil Phosphatase Activities. Air-dried soil samples passed through a $2 \mathrm{~mm}$ sieve were used to analyze phosphomonoesterases (acid and alkaline phosphatases) and phosphodiesterase activities as described by Tabatabai [22]. The methods are based on colorimetric determination of $p$ nitrophenol released by phosphatase activity when soil is incubated with buffered substrates at each enzyme's optimal $\mathrm{pH}$ [22]. Acid and alkaline phosphatase assays were performed in a modified universal buffer containing $10 \mathrm{mM} p$ nitrophenyl phosphate at $\mathrm{pH} 6.5$ and $\mathrm{pH} 11$, respectively. 
Phosphodiesterase assay was performed at $\mathrm{pH} 8$ with $10 \mathrm{mM}$ p-nitrophenyl phosphate serving as the substrate. All analyses were done in triplicate.

2.4. Soil Microbial Community Analyses. The homogenized subsamples were taken for extraction of lipids and DNA. Field moist soil samples were stored at $4^{\circ} \mathrm{C}$ for no more than two weeks before lipid extraction and at $-20^{\circ} \mathrm{C}$ until soil DNA extraction.

2.4.1. Phospholipid Fatty Acid (PLFA) Analysis. Phospholipid fatty acid analysis was performed as described by Feng et al. [12]. It involved extraction of total lipids from soil, fractionation of total lipids, derivatization of fatty acids to form fatty acid methyl esters (FAMEs), and GC analysis of FAMEs. Briefly, duplicate field moist soil samples $(8 \mathrm{~g}$ dry weight) from each of the 16 composite samples were used for extracting total lipids using a single-phase citrate buffer-chloroform-methanol solution $(1: 2: 0.8 \mathrm{v} / \mathrm{v} / \mathrm{v}, \mathrm{pH}$ 4). The phospholipids were separated from neutral lipids and glycolipids using silicic acid column chromatography. The phospholipids were then subjected to a mild alkaline methanolysis, and resulting FAMEs were extracted using hexane and dried under nitrogen gas. The FAMEs containing 19:0 methyl ester as an internal standard were analyzed using a Hewlett Packard 5890 gas chromatograph with a $25 \mathrm{~m}$ HP Ultra 2 capillary column and a flame ionization detector. FAME peaks were identified using the MIDI peak identification software (MIDI, Inc., Newark, DE, USA) and quantified based on the internal standard added. The nomenclature for fatty acids used here was described by Feng et al. [12].

2.4.2. Automated Ribosomal Intergenic Spacer Analysis (ARISA). ARISA involved total community DNA extraction from soil, PCR amplification using fluorescence-tagged oligonucleotide primers targeting intergenic transcribed spacer region, automated electrophoresis, laser detection of fluorescent DNA fragments, and analysis of banding patterns. Total soil DNA was extracted from $8 \mathrm{~g}$ of moist soil using a PowerMax Soil DNA Kit (MoBio Labs Inc., Carlsbad, CA, USA) following the manufacturer's instructions. The extracted DNA was quantified using a NanoDrop ND-1000 Spectrophotometer (Thermo Fisher Scientific, Wilmington, DE, USA) and stored at $-80^{\circ} \mathrm{C}$ until use. Both bacterial and fungal ARISAs were performed to determine soil microbial community structure.

The bacterial primers used in the PCR reactions were ITSF ( $5^{\prime}$-GTCGTAACAAGGTAGCCGTA-3') and ITSReub $\left(5^{\prime}\right.$-GCCAAGGCATCCACC- $\left.3^{\prime}\right)$ [23]. The reaction mixture contained $12.5 \mu \mathrm{L}$ of $2 \mathrm{X}$ GoTaq colorless master mix (Promega, Madison, WI, USA), $25 \mu \mathrm{g}$ of bovine serum albumin (Sigma-Aldrich Co., St. Louis, MO, USA), $0.2 \mu \mathrm{M}$ of ITSF primer, $0.2 \mu \mathrm{M}$ of ITSF primer labeled with IRD800 fluorochrome (LI-COR, Lincoln, Nebraska), $0.4 \mu \mathrm{M}$ of ITSReub primer, $5 \mu \mathrm{L}$ of template DNA ( $20 \mathrm{ng}$ ), and nuclease-free water to make the final volume to $25 \mu \mathrm{L}$. Amplification was performed on a Biometra T-Gradient thermocycler (Whatmann, Goettingen, Germany) using the following cycling parameters: $3 \mathrm{~min}$ at $94^{\circ} \mathrm{C}, 30$ cycles of $60 \mathrm{~s}$ at $94^{\circ} \mathrm{C}$, $30 \mathrm{~s}$ at $55^{\circ} \mathrm{C}$ and $60 \mathrm{~s}$ at $72^{\circ} \mathrm{C}$, and a final $5 \mathrm{~min}$ at $72^{\circ} \mathrm{C}$ [24].

The fungal automated intergenic spacer analyses were performed using ITS1F (5'-CTTGGTCATTTAGAGGAAGTAA- $\left.3^{\prime}\right)$ and 3126T ( $5^{\prime}$-ATATGCTTAAGTTCAGCGGGT-3') $[25,26]$. The reaction mixture $(25 \mu \mathrm{L})$ consisted of $12.5 \mu \mathrm{L}$ of $2 \mathrm{X}$ GoTaq colorless master mix, $25 \mu \mathrm{g}$ of bovine serum albumin, $0.3 \mu \mathrm{M}$ of ITS1F primer, $0.1 \mu \mathrm{M}$ of ITS1F primer labeled with IRD800 fluorochrome, $0.4 \mu \mathrm{M}$ of $3126 \mathrm{~T}$ primer, and $5 \mu \mathrm{L}$ of template DNA ( $20 \mathrm{ng})$. The thermocycling conditions were as follows: $4 \mathrm{~min}$ at $95^{\circ} \mathrm{C}, 35$ cycles of $60 \mathrm{~s}$ at $95^{\circ} \mathrm{C}, 30 \mathrm{~s}$ at $53^{\circ} \mathrm{C}$ and $60 \mathrm{~s}$ at $72^{\circ} \mathrm{C}$, and a final $7 \mathrm{~min}$ at $72^{\circ} \mathrm{C}[27,28]$.

A total of $5 \mu \mathrm{L}$ amplified PCR products $(2.5 \mu \mathrm{L}$ from each replicate) was mixed with $2.5 \mu \mathrm{L}$ of stop buffer (LICOR Blue Stop Solution), denatured at $95^{\circ} \mathrm{C}$ for $2 \mathrm{~min}$, and then placed on ice. The denatured PCR products $(0.8-1 \mu \mathrm{L})$ were loaded on $6 \%$ polyacrylamide gel along with $0.8 \mu \mathrm{L}$ of the IRD800 50-700 bp sizing standard (LI-COR). ARISA fragments were resolved under denaturing conditions for 9 hours at $1,500 \mathrm{~V}$ using the LI-COR 4300 sequencer. Laserscanned banding pattern image from the LI-COR sequencer was converted to 8-bit TIFF using Kodak 1D Image Analysis Software (Eastman Kodak Co., Rochester, NY, USA).

2.5. Data Analysis. All microbial parameters were converted to unit weight of dry soil prior to data analysis. Data for general soil physicochemical and biological properties were analyzed using PROC MIXED and multiple comparison procedure as well as principal components analysis. The mole percent distribution of PLFAs was analyzed using principal components analysis (PROC PRINCOMP, SAS ver.9.1.3). Analysis of PLFA profiles was performed using a set of 50 fatty acids that were present in most of the samples. Bacterial biomass was calculated using the sum of 15 bacterial markers, that are, 14:0, 15:0, a15:0, i15:0, i16:0, 16:1 $\omega 5$, $16: 1 \omega 7,16: 1 \omega 9,17: 0$, a17:0, i17:0, 18:0, 18:1 $\omega 7$, cy17:0, and cy19:0 [29, 30]. Fungal biomass was assessed using 18:2 $\omega 6$, 9 [31] and physiological stress by the ratio of cy19:0/18:1 $\omega 7$ $[32,33]$. The fungal to bacterial PLFA ratio was calculated

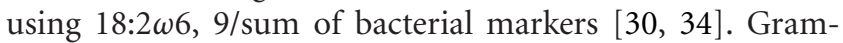
negative to Gram-positive bacteria were calculated using $(\mathrm{i} 15: 0+\mathrm{a} 15: 0+\mathrm{i} 16: 0+10 \mathrm{Me} 16: 0) /(16: 1 \omega 7+18: 1 \omega 7+$ cy19:0). The PLFA biomarkers and ratios were also analyzed using PROC MIXED and multiple comparison procedure.

ARISA-banding pattern images were processed using the software BIONUMERICS Ver. 5.0 (Applied Maths, Belgium). Each image was normalized using the $50-700 \mathrm{bp}$ sizing standard as the external reference standard, which allowed for comparison of multiple gels. Levels of similarity between DNA fingerprints were compared using a densitometric curve-based method with the cosine coefficient after the conversion, normalization, and background subtraction with mathematical algorithms of banding patterns. Dendrograms were developed using cluster analysis performed with the cosine similarity coefficient and unweighted pair-group method using average linkages (UPGMA). The position tolerance was set at an optimization of $0.5 \%$, and band comparison was made using a position tolerance of $1 \%$. Principal 
TABLE 1: Selected chemical and physical properties of soils from no-till (NT) and conventional-till (CT) treatments*.

\begin{tabular}{|c|c|c|c|c|c|c|c|}
\hline Tillage treatment & Depth $(\mathrm{cm})$ & Organic C (\%) & Total N(\%) & $\mathrm{C} / \mathrm{N}$ ratio & Bulk density $\left(\mathrm{Mg} \mathrm{m}^{-3}\right)$ & Soil pH $\left(1: 2 \mathrm{CaCl}_{2}\right)$ & $\begin{array}{c}\text { Soil moisture } \\
\text { content }\end{array}$ \\
\hline NT & $0-5$ & $1.94 \mathrm{a}$ & $0.13 a$ & $14.9 \mathrm{a}$ & $1.52 \mathrm{~b}$ & $6.1 \mathrm{a}$ & $0.25 a$ \\
\hline NT & $5-15$ & $0.84 \mathrm{~b}$ & $0.07 b$ & $11.7 \mathrm{~b}$ & $1.65 \mathrm{a}$ & $5.9 \mathrm{a}$ & $0.18 b$ \\
\hline $\mathrm{CT}$ & $0-5$ & $0.92 b$ & $0.08 \mathrm{~b}$ & $11.0 \mathrm{~b}$ & $1.53 \mathrm{~b}$ & $6.1 \mathrm{a}$ & $0.15 c$ \\
\hline $\mathrm{CT}$ & $5-15$ & $0.76 b$ & $0.07 \mathrm{~b}$ & $10.9 \mathrm{~b}$ & $1.66 \mathrm{a}$ & $6.2 \mathrm{a}$ & $0.12 \mathrm{~d}$ \\
\hline
\end{tabular}

${ }^{*}$ Means $(n=4)$ followed by the same letter in a column are not significantly different (Tukey, $P \leq 0.05$ ).

TABle 2: Total PLFAs and phosphatase ${ }^{\dagger}$ activities in no-till (NT) and conventional-till (CT) soils*.

\begin{tabular}{lccccc}
\hline Tillage treatment & Depth $(\mathrm{cm})$ & Total PLFAs $\left(\mathrm{nmol} \mathrm{g}^{-1}\right)$ & Acid P & $\begin{array}{c}\text { Alk P } \\
\left(\mu \text { g of } p \text {-nitrophenol g-1 } \mathrm{hr}^{-1}\right)\end{array}$ \\
\hline NT & $0-5$ & $104 \mathrm{a}$ & $367 \mathrm{a}$ & $321 \mathrm{a}$ & $132 \mathrm{a}$ \\
NT & $5-15$ & $38 \mathrm{~b}$ & $307 \mathrm{ab}$ & $44 \mathrm{c}$ & $36 \mathrm{~b}$ \\
CT & $0-5$ & $39 \mathrm{~b}$ & $200 \mathrm{~b}$ & $89 \mathrm{~b}$ & $32 \mathrm{~b}$ \\
CT & $5-15$ & $30 \mathrm{c}$ & $202 \mathrm{~b}$ & $87 \mathrm{~b}$ \\
\hline
\end{tabular}

${ }^{\dagger}$ Acid P, acid phosphatase; Alk P, alkaline phosphatase; PDE, phosphodiesterase.

* Means $(n=4)$ followed by the same letter in a column are not significantly different (Tukey, $P \leq 0.05$ ).

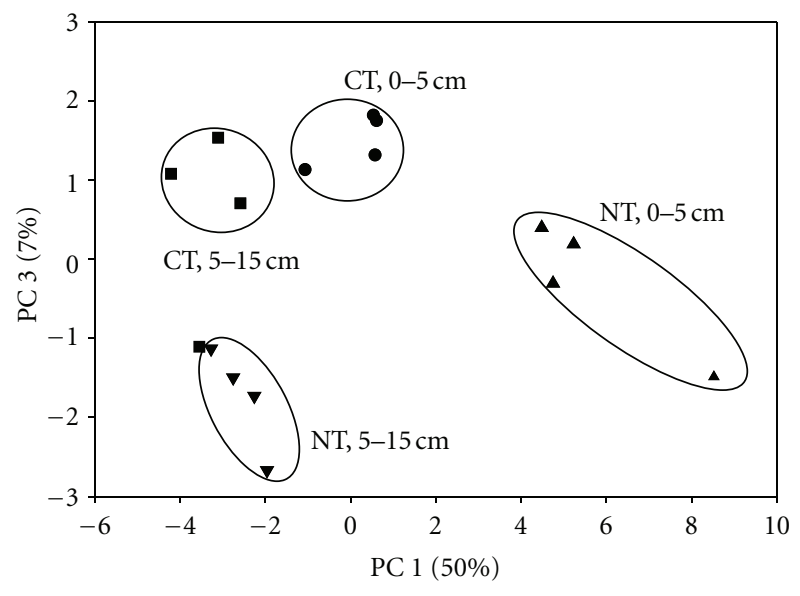

FIGURE 1: Principal components analysis of PLFA profiles.

components analysis was used to determine distribution of fingerprint patterns according to different tillage treatment and soil depth.

\section{Results}

3.1. Soil Physicochemical and Biochemical Properties. Physicochemical characteristics of surface soils differed between tillage treatments (Table 1). Soil organic C, total N, and C/N ratios were significantly higher in the no-till treatment than the conventional tillage treatment at the $0-5 \mathrm{~cm}$ depth but not at the lower depth. Depth effects were observed only in the no-till treatment. Bulk density for surface soil in both no-till and conventional-till treatments was lower compared with the subsurface soil although no significant difference was observed between tillage treatments. Soil $\mathrm{pH}$ values did not vary by tillage treatment or soil depth.
Total PLFA concentrations, an indicator of viable microbial biomass, ranged from $30 \mathrm{nmol} / \mathrm{g}$ of soil for the conventional-till treatment at the $5-15 \mathrm{~cm}$ depth to $104 \mathrm{nmol} / \mathrm{g}$ of soil for the no-till treatment at the $0-5 \mathrm{~cm}$ depth (Table 2 ). The total PLFA concentration in the no-till surface soil was 2.7 times higher than in the conventionally tilled soil. As soil depth increased, total PLFA concentrations decreased in both tillage treatments. Soil phosphatase activities showed a similar trend with no-till soil having significantly higher activities than conventionally tilled soil at the 0 to $5 \mathrm{~cm}$ depth (Table 2 ). In the no-till treatment, the enzyme activities were significantly higher at the 0 to $5 \mathrm{~cm}$ than at the 5 to $15 \mathrm{~cm}$ depth except for acid phosphatase. Among three soil phosphatases, acid phosphatase activity was the highest, ranging from 200 to $367 \mu \mathrm{g}$ of $p$-nitrophenol $\mathrm{g}^{-1} \mathrm{hr}^{-1}$. Alkaline phosphatase activities ranged from 44 to 321 and phosphodiesterase from 32 to $132 \mu \mathrm{g}$ of $p$-nitrophenol $\mathrm{g}^{-1} \mathrm{hr}^{-1}$.

3.2. PLFA. Principal components analysis of PLFA profiles showed that $81 \%$ of the total sample variation was explained by the first three principal components (PCs). PC 1 explained $50 \%$ of the total variation and separated the soil depth effect. PC 3 explained $7 \%$ of the variation and separated the tillage effect (Figure 1). The influential fatty acids for the first principal component (Table 3 ) were an actinobacterial biomarker

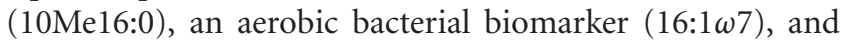

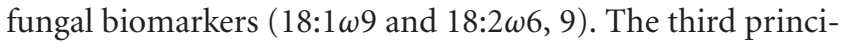
pal component was influenced mostly by a nonspecific fatty acid (i17:1), an anaerobic bacterial biomarker (cy19:0), and an actinobacterial biomarker (10Me16:0) (Table 3).

The relative abundance of fungal biomarker $(18: 2 \omega 6,9)$ as indicated by mole percentage did not show tillage treatment effect; however, the concentration of this biomarker was higher in no-till than conventionally tilled soil at the surface depth (Table 4). The sum of bacterial PLFAs showed a similar trend. Similar to the relative abundance of fungal 
TABLE 3: PLFA having scores $>| \pm 0.23|$ for the first and third principal components.

\begin{tabular}{|c|c|c|}
\hline Fatty acid & Score & Specificity as a biomarker* \\
\hline \multicolumn{3}{|l|}{ PC 1} \\
\hline $10 \mathrm{Me} 16: 0$ & -0.65 & Actinobacteria \\
\hline $16: 1 \omega 7$ & 0.32 & Aerobic bacteria \\
\hline $18: 1 \omega 9$ & 0.29 & Fungi \\
\hline $18: 2 \omega 6,9$ & 0.23 & Fungi \\
\hline \multicolumn{3}{|l|}{ PC 3} \\
\hline i17:1 & -0.51 & Nonspecific \\
\hline cy19:0 & -0.34 & Anaerobic bacteria \\
\hline 10Me16:0 & 0.30 & Actinobacteria \\
\hline
\end{tabular}

* Source: Findlay [48] and Paul and Clark [49].

and bacterial PLFAs, the fungal to bacterial PLFA ratios showed depth but not tillage treatment effects. Although arbuscular mycorrhizal (AM) fungi proportions only showed the depth effect, concentrations of the AM fungal biomarker (16:1 $\omega 5)$ showed both tillage and depth effects. The relative abundance of the actinobacterial biomarker (10Me18:0) was similar across tillage treatments and soil depths, whereas its concentrations differed by tillage and depth. Gram-positive to Gram-negative bacterial PLFA ratios (Table 4) and the stress indicator ratios (cy19:0/18:1 $\omega 7$, data not shown) did not show any significant difference for tillage treatment or depth.

3.3. ARISA. Principal components analysis of bacterial ARISA profiles showed that the first and second principal components explained $68 \%$ and $23 \%$ of the total sample variation, respectively (Figure 2(a)). The first principal component separated the no-tillage from conventional tillage treatment, and the second principal component separated the no-till treatment by soil depth. There was no depth separation for the conventional tillage treatment. Principal components analysis of fungal ARISA profiles showed that the first and second principal components explained 54\% and $25 \%$ of the total sample variation, respectively (Figure 2(b)). The first principal component separated the tillage effect, while the second principal component separated the surface and subsurface soil for the no-till treatment.

\subsection{Interactions between Soil Physicochemical and Biochem-} ical Variables. Correlation and multivariate analyses were performed to determine interactions between soil physicochemical and biochemical variables. Acid and alkaline phosphatases as well as phosphodiesterase activities were positively correlated to soil organic carbon and soil moisture contents (Table 5). Soil bulk density was negatively correlated with alkaline phosphatase $(r=-0.56)$ and phosphodiesterase $(r=-0.46)$ activities but had no significant correlation with acid phosphatase activities. Total PLFAs were highly correlated with soil organic carbon $(r=0.98)$ and moisture content $(r=0.87)$. The fungal to bacterial PLFA ratios and proportions of AM fungal biomarker as well as the

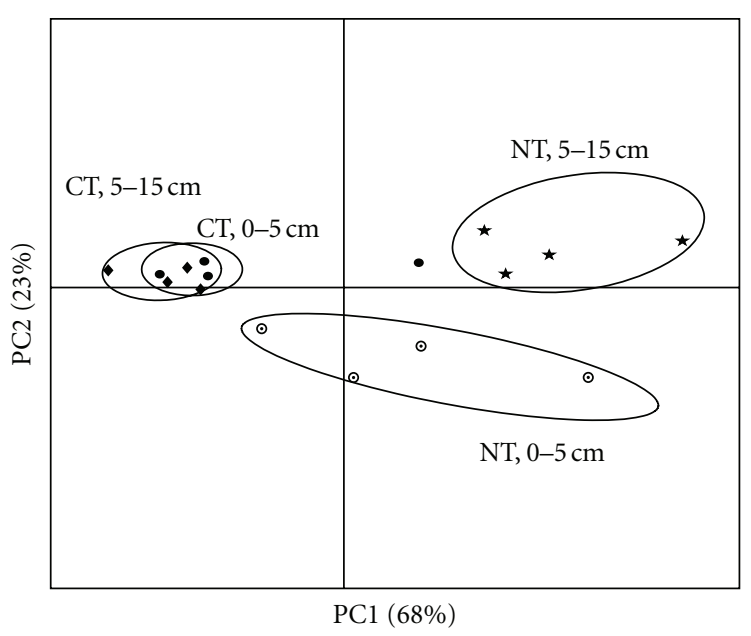

(a) Bacteria

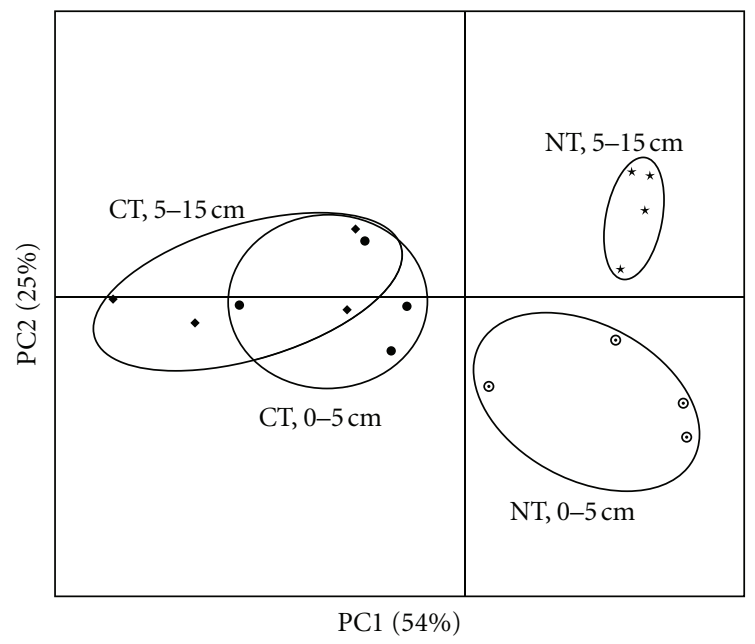

(b) Fungi

FIGURE 2: Principal components analyses of bacterial (a) and fungal (b) ARISA profiles.

fungal biomarker were also positively correlated with soil organic carbon (Table 5). Bacterial PLFA proportions were negatively correlated with both soil organic carbon and moisture content but positively correlated with bulk density. The fungal biomarker and the fungal to bacterial PLFA ratio were negatively correlated with soil bulk density. The relative abundance of AM fungal biomarker was positively correlated with soil moisture content.

Multivariate analysis using selected soil physicochemical and enzyme variables (i.e., soil organic carbon, total nitrogen, soil moisture, soil $\mathrm{pH}$, bulk density, acid and alkaline phosphatases, and phosphodiesterase) also revealed tillage and depth effects (Figure 3). Principal components analysis showed that the first principal component explained $68 \%$ of the total sample variation and the second principal component $17 \%$. Data points for the no-tillage treatment at the surface depth formed a distinct cluster by themselves. Data points for the conventional tillage treatment at both depths clustered together, whereas those for the no-till 


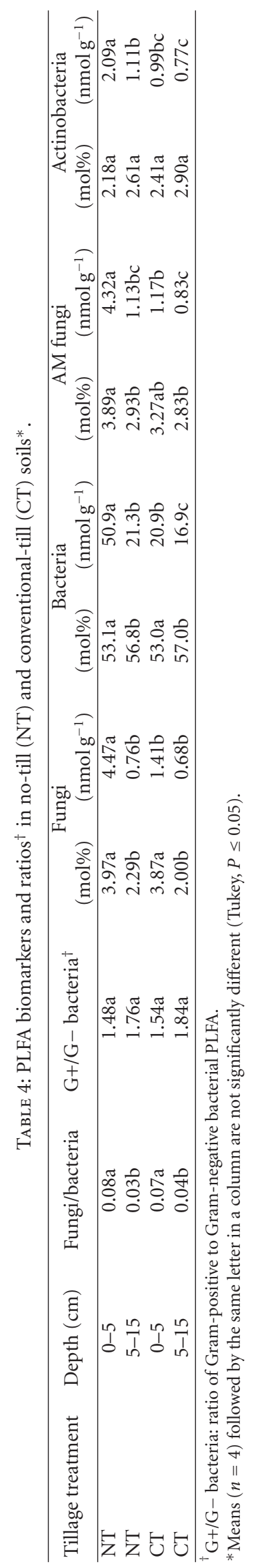


TABLE 5: Correlation coefficients between soil physicochemical and biochemical variables determined in the study.

\begin{tabular}{lcccccccc}
\hline \multirow{2}{*}{ Soil property } & \multicolumn{3}{c}{ Phosphatase activity $^{\dagger}$} & \multicolumn{4}{c}{ PLFA biomarkers and ratios } \\
& Acid P & Alk P & PDE & Total PLFA & Fungi & Bacteria & Fungi/bacteria & AM fungi \\
\hline Soil organic carbon & 0.72 & 0.95 & 0.92 & 0.98 & 0.53 & -0.65 & 0.56 \\
Soil moisture content & 0.77 & 0.84 & 0.90 & 0.87 & NS & -0.39 & NS \\
Bulk density & NS* & -0.56 & -0.46 & -0.53 & -0.62 & 0.49 & -0.60 & NS \\
\hline
\end{tabular}

${ }^{\dagger}$ Acid P, acid phosphatase; Alk P, alkaline phosphatase; PDE, phosphodiesterase;

*NS: No significant correlation $(P \leq 0.05)$.

TABLE 6: Soil physicochemical and enzyme variables having scores $\geq| \pm 0.38|$ for the first two principal components.

\begin{tabular}{lc}
\hline Soil properties & Score \\
\hline PC 1 & \\
Soil organic carbon & 0.42 \\
Total nitrogen & 0.41 \\
Alkaline phosphatase & 0.41 \\
Phosphodiesterase & 0.41 \\
Soil moisture & 0.38 \\
PC 2 & \\
Soil pH $\left(1: 2 \mathrm{CaCl}_{2}\right)$ & 0.81 \\
\hline
\end{tabular}

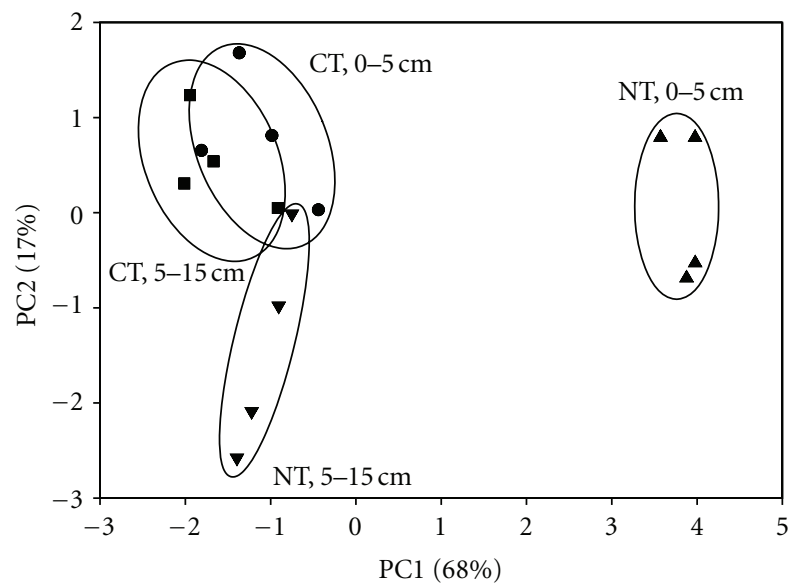

Figure 3: Principal components analysis using soil physicochemical and enzyme variables.

treatment formed two clusters separated by soil depth. The influential variables for the first principal component were soil organic carbon, total nitrogen, alkaline phosphatase, phosphodiesterase, and soil moisture and that for the second principal component was soil pH (Table 6).

\section{Discussion}

Changes in soil characteristics associated with adoption of conservation tillage systems generally result in improved soil quality, especially in the southeastern USA where soils are inherently low in fertility and susceptible to aggregate disruption and erosion. In this study, soil under the longterm no-till treatment had higher soil carbon and nitrogen contents, total PLFAs, and phosphatase activities at the $0-5$ depth than that under the conventional-till treatment. Tillage treatment effects were less pronounced at the $5-15 \mathrm{~cm}$ depth. These observations are in agreement with previous findings reported by, for example, Ceja-Navarro et al. [35], Drijber et al. [36], Ekenler and Tabatabai [37], Feng et al. [12], Helgason et al. [13], and Ibekwe et al. [15]. Total PLFAs in the no-till surface soil were much higher than those reported in a previous study during the fallow period [12] conducted on the same soil type although organic carbon contents at the two sites were similar. This may be attributed the difference in the cropping systems: continuous cotton with no winter cover crop in the previous study versus continuous corn with rye as a winter cover crop in this study. Cotton is known to generate lesser residues than corn [38], and the rye cover crop provided additional organic matter input to the soil. Three years of corn/rye cropping system perhaps were not long enough for observing a significant change in soil organic matter; the increase in microbial biomass as indicated by total PLFAs, however, provides another line of evidence that microorganisms are sensitive and early indicators for soil quality evaluation. The findings of tillage treatment and depth effects on phosphatase activities were consistent with the study of Ekenler and Tabatabai [37]. Soil enzymes have been suggested as soil quality indicators owing to their relationship to soil biology and rapid response to changes in soil management and ease of measurement [39].

In no-till soils, the accumulation of crop residues on the soil surface results in enrichment of soil organic matter in the surface layer and as a consequence increased abundance of microorganisms. This study demonstrated a consistent increase in the abundance of fungi, bacteria, arbuscular mycorrhizal fungi, and actinobacteria in the no-till surface soil. Similar to other reports (e.g., Feng et al. [12]; Helgason et al. [13]; Pankhurst et al. [40]), this study did not show a fungal dominance in the no-till soil as indicated by the ratio of fungal to bacterial PLFAs. The relative abundance of fungi under no-till practices has been shown to be greater than that under conventional-till practices when fungal biomass was determined by measuring hyphal length [41]. This discrepancy may be attributed to differences in the methods used. As pointed out by Helgason et al. [13], microscopic measurements of fungal hyphal length performed by Frey et al. [41] include both viable and nonviable fungal hyphae. PLFA analysis on the other hand provides a measure of viable microbial biomass. Additional factors to be taken into account include that (1) different groups of microorganisms share overlapping PLFAs also contribute to the discrepancy 
and (2) phospholipid concentrations in fungi are lower than those in bacteria. Nevertheless, comparison of fungal to bacterial PLFA ratios between tillage treatments is warranted.

Polyphasic approaches are often used to study soil microbial communities. PLFA analysis has been shown to be the best approach to discern a treatment effect on soil microbial community and be able to differentiate treatments that are not resolved by PCR-based methods in some cases [42]. In this study, both PLFA analysis and ARISA clearly demonstrated the shift in soil microbial communities associated with tillage practices. These findings are consistent with those reported by Drijber et al. [36], Feng et al. [12], and Peixoto et al. [43]. The observed changes in soil microbial communities can be attributed to favorable physical and chemical conditions under the no-tillage system for microbial activities. A closer examination of principal components analysis results for PLFA and ARISA profiles (Figures 1 and 2) revealed that the depth effect for conventionally tilled soil was more pronounced in PLFA analysis. This suggests that in addition to bacteria and fungi, microfauna (e.g., protozoa and nematodes) may contribute to the discrimination of the subtle difference between soil depths in the relatively well mixed conventionally tilled soil since eukaryotic organisms other than fungi contribute to the soil PLFAs.

ARISA is an automated DNA fingerprinting method targeting the intergenic spacer regions of bacteria and fungi in PCR; it is highly reproducible and effective in detecting changes in soil microbial community structure. Bacterial and fungal ARISA have previously been used in studies conducted on agricultural and forest soils $[44,45]$. To our knowledge, this is the first time that ARISA was used to determine the impact of tillage practices on soil microbial communities. Although it provides information on genetic community structure of soil bacteria and fungi, the intergenic spacer regions targeted by ARISA cannot be used to identify dominant organisms. Little information is available regarding the specific microorganisms affected by different tillage practices. Ceja-Navarro et al. [35] conducted phylogenetic and multivariate analyses to determine the effects of zero tillage and conventional tillage on soil bacterial communities in a long-term maize-wheat rotation experiment. They found that bacterial communities under zero tillage and crop residue retention have the highest level of diversity and richness. Zero tillage has a positive effect on members of Rhizobiales and crop residue retention increases fluorescent Pseudomonas spp. and Burkholderiales group. In a rice-soybean rotation study, impact of conventional and notillage with and without cover crops on soil bacterial community structure was determined using PCR-DGGE without identification of bands through DNA sequencing [43]. Responses of bacterial communities to cultivation, tillage, and soil depth but not to cover cropping were detected.

Results of principal components analysis based on soil physicochemical and enzyme variables (Figure 3 ) were in general agreement with those based on PLFA and ARISA profiles. Soil organic carbon was the most influential factor for PC 1, confirming its critical role in the no-till system. Soil organic carbon was correlated with all biochemical variables except for the relative abundance of bacterial biomarkers. A negative correlation between soil organic carbon and bacterial PLFAs has also been observed by Zornoza et al. [46] and Helgason et al. [13]. Lauber et al. [47] quantified microbial communities by quantitative PCR and also reported lack of correlation between soil carbon and bacterial population. They showed that soil $\mathrm{pH}$ and texture are better predictors of soil bacteria.

\section{Conclusions}

In this study, soil under the long-term no-till treatment had higher soil carbon and nitrogen contents, total PLFAs, and phosphatase activities at the $0-5 \mathrm{~cm}$ depth than that under the conventional tillage treatment. Differences between tillage treatments at the $5-15 \mathrm{~cm}$ depth were negligible with the exception of alkaline phosphatase activities. Soil microbial communities shifted with tillage treatment and soil depth. Tillage practice and soil depth were two important factors affecting soil microbial communities. PLFA analysis and ARISA showed comparable results on treatment effects. PLFA profiles, however, detected differences in microbial communities associated with soil depth in the conventional tillage treatment. This study demonstrated that tillage systems influence soil microbial communities along with soil physicochemical properties. Further research is needed to determine the influence of tillage-induced changes on soil microbial community composition (i.e., the identity of key organisms) and their dynamics.

\section{Acknowledgments}

The authors would like to thank Dr. Zhanjiang (John) Liu for the use of LI-COR 4300 sequencer in the Fish Molecular Genetics and Biotechnology Laboratory at Auburn University and Dr. Edzard Van Santen for helping with statistical analysis. This work was supported, in part, by grants from the Alabama Agricultural Land-Grant Alliance and the Alabama Agricultural Experiment Station.

\section{References}

[1] P. R. Hobbs, K. Sayre, and R. Gupta, "The role of conservation agriculture in sustainable agriculture," Philosophical Transactions of the Royal Society B, vol. 363, no. 1491, pp. 543-555, 2008.

[2] R. Alvarez, "A review of nitrogen fertilizer and conservation tillage effects on soil organic carbon storage," Soil Use and Management, vol. 21, no. 1, pp. 38-52, 2005.

[3] N. D. Uri, "Factors affecting the use of conservation tillage in the United States," Water, Air, and Soil Pollution, vol. 116, no. 3-4, pp. 621-638, 1999.

[4] E. B. Schwab, D. W. Reeves, C. H. Burmester, and R. L. Raper, "Conservation tillage systems for cotton in the Tennessee Valley," Soil Science Society of America Journal, vol. 66, no. 2, pp. 569-577, 2002.

[5] T. O. West and W. M. Post, "Soil organic carbon sequestration rates by tillage and crop rotation: a global data analysis," Soil Science Society of America Journal, vol. 66, no. 6, pp. 19301946, 2002. 
[6] M. M. Wander, M. G. Bidart, and S. Aref, "Tillage impacts on depth distribution of total and particulate organic matter in three Illinois soils," Soil Science Society of America Journal, vol. 62, no. 6, pp. 1704-1711, 1998.

[7] M. D. Trojan and D. R. Linden, "Macroporosity and hydraulic properties of earthworm-affected soils as influenced by tillage and residue management," Soil Science Society of America Journal, vol. 62, no. 6, pp. 1687-1692, 1998.

[8] R. H. Azooz, M. A. Arshad, and A. J. Franzluebbers, "Pore size distribution and hydraulic conductivity affected by tillage in Northwestern Canada," Soil Science Society of America Journal, vol. 60, no. 4, pp. 1197-1201, 1996.

[9] K. Y. Chan and J. A. Mead, "Surface physical properties of a sandy loam soil under different tillage practices," Australian Journal of Soil Research, vol. 26, no. 3, pp. 549-559, 1988.

[10] E. Kandeler, D. Tscherko, and H. Spiegel, "Long-term monitoring of microbial biomass, $\mathrm{N}$ mineralisation and enzyme activities of a chernozem under different tillage management," Biology and Fertility of Soils, vol. 28, no. 4, pp. 343-351, 1999.

[11] T. E. Staley, "Soil microbial biomass alterations during the maize silage growing season relative to tillage method," Soil Science Society of America Journal, vol. 63, no. 6, pp. 18451847, 1999.

[12] Y. Feng, A. C. Motta, D. W. Reeves, C. H. Burmester, E. Van Santen, and J. A. Osborne, "Soil microbial communities under conventional-till and no-till continuous cotton systems," Soil Biology and Biochemistry, vol. 35, no. 12, pp. 1693-1703, 2003.

[13] B. L. Helgason, F. L. Walley, and J. J. Germida, "Fungal and bacterial abundance in long-term no-till and intensive-till soils of the Northern Great Plains," Soil Science Society of America Journal, vol. 73, no. 1, pp. 120-127, 2009.

[14] E. L. Balota, A. Colozzi-Filho, D. S. Andrade, and R. P. Dick, "Microbial biomass in soils under different tillage and crop rotation systems," Biology and Fertility of Soils, vol. 38, no. 1, pp. 15-20, 2003.

[15] A. M. Ibekwe, A. C. Kennedy, P. S. Frohne, S. K. Papiernik, C. H. Yang, and D. E. Crowley, "Microbial diversity along a transect of agronomic zones," FEMS Microbiology Ecology, vol. 39, no. 3, pp. 183-191, 2002.

[16] A. Frostegard, A. Tunlid, and E. Baath, "Phospholipid fatty acid composition, biomass, and activity of microbial communities from two soil types experimentally exposed to different heavy metals," Applied and Environmental Microbiology, vol. 59, no. 11, pp. 3605-3617, 1993.

[17] M. M. Fisher and E. W. Triplett, "Automated approach for ribosomal intergenic spacer analysis of microbial diversity and its application to freshwater bacterial communities," Applied and Environmental Microbiology, vol. 65, no. 10, pp. 46304636, 1999.

[18] R. G. Burns, "Extracellular enzyme-substrate interactions in soil," in Microbes in their Natural Environment, R. W. J. H. Slater and J. W. T. Wimpenny, Eds., pp. 249-298, Cambridge University Press, London, UK, 1983.

[19] R. L. Sinsabaugh, R. K. Antibus, and A. E. Linkins, "An enzymic approach to the analysis of microbial activity during plant litter decomposition," Agriculture, Ecosystems and Environment, vol. 34, no. 1-4, pp. 43-54, 1991.

[20] R. P. Dick, J. A. Sandor, and N. S. Eash, "Soil enzyme activities after 1500 years of terrace agriculture in the Colca Valley, Peru," Agriculture, Ecosystems and Environment, vol. 50, no. 2, pp. 123-131, 1994.

[21] W. A. Dick and M. A. Tabatabai, "Potential uses of soil enzymes," in Soil Microbial Ecology: Applications in Agricultural and Environmental Management, F. B. Metting Jr, Ed., pp. 95127, Marcel Dekker, New York, NY, USA, 1992.

[22] M. A. Tabatabai, "Soil enzymes," in Methods of Soil Analysis. Part 2-Chemical and Microbiological Properties, A. L. Page, R. H. Miller, and D. R. Keeney, Eds., pp. 775-883, Soil Science Society of America, Madison, Wis, USA, 1994.

[23] M. Cardinale, L. Brusetti, P. Quatrini et al., "Comparison of different primer sets for use in automated ribosomal intergenic spacer analysis of complex bacterial communities," Applied and Environmental Microbiology, vol. 70, no. 10, pp. 6147-6156, 2004.

[24] L. Ranjard, F. Poly, J. Combrisson et al., "Heterogeneous cell density and genetic structure of bacterial pools associated with various soil microenvironments as determined by enumeration and DNA fingerprinting approach (RISA)," Microbial Ecology, vol. 39, no. 4, pp. 263-272, 2000.

[25] B. Nicolardot, L. Bouziri, F. Bastian, and L. Ranjard, "A microcosm experiment to evaluate the influence of location and quality of plant residues on residue decomposition and genetic structure of soil microbial communities," Soil Biology and Biochemistry, vol. 39, no. 7, pp. 1631-1644, 2007.

[26] L. Ranjard, A. Echairi, V. Nowak, D. P. H. Lejon, R. Nouaïm, and R. Chaussod, "Field and microcosm experiments to evaluate the effects of agricultural $\mathrm{Cu}$ treatment on the density and genetic structure of microbial communities in two different soils," FEMS Microbiology Ecology, vol. 58, no. 2, pp. 303-315, 2006.

[27] N. Kennedy, J. Connolly, and N. Clipson, "Impact of lime, nitrogen and plant species on fungal community structure in grassland microcosms," Environmental Microbiology, vol. 7, no. 6, pp. 780-788, 2005.

[28] N. Kennedy, S. Edwards, and N. Clipson, "Soil bacterial and fungal community structure across a range of unimproved and semi-improved upland grasslands," Microbial Ecology, vol. 50, no. 3, pp. 463-473, 2005.

[29] A. Frostegård and E. Bååth, "The use of phospholipid fatty acid analysis to estimate bacterial and fungal biomass in soil," Biology and Fertility of Soils, vol. 22, no. 1-2, pp. 59-65, 1996.

[30] T. A. Spedding, C. Hamel, G. R. Mehuys, and C. A. Madramootoo, "Soil microbial dynamics in maize-growing soil under different tillage and residue management systems," Soil Biology and Biochemistry, vol. 36, no. 3, pp. 499-512, 2004.

[31] C. Kaiser, A. Frank, B. Wild, M. Koranda, and A. Richter, "Negligible contribution from roots to soil-borne phospho-

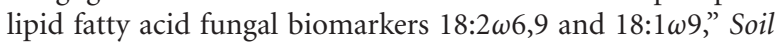
Biology and Biochemistry, vol. 42, no. 9, pp. 1650-1652, 2010.

[32] L. E. Jackson, F. J. Calderon, K. L. Steenwerth, K. M. Scow, and D. E. Rolston, "Responses of soil microbial processes and community structure to tillage events and implications for soil quality," Geoderma, vol. 114, no. 3-4, pp. 305-317, 2003.

[33] J. Moore-Kucera and R. P. Dick, "PLFA profiling of microbial community structure and seasonal shifts in soils of a Douglasfir chronosequence," Microbial Ecology, vol. 55, no. 3, pp. 500$511,2008$.

[34] S. A. Boyle, R. R. Yarwood, P. J. Bottomley, and D. D. Myrold, "Bacterial and fungal contributions to soil nitrogen cycling under Douglas fir and red alder at two sites in Oregon," Soil Biology and Biochemistry, vol. 40, no. 2, pp. 443-451, 2008.

[35] J. A. Ceja-Navarro, F. N. Rivera-Orduña, L. Patiño-Zúñiga et al., "Phylogenetic and multivariate analyses to determine the effects of different tillage and residue management practices on soil bacterial communities," Applied and Environmental Microbiology, vol. 76, no. 11, pp. 3685-3691, 2010. 
[36] R. A. Drijber, J. W. Doran, A. M. Parkhurst, and D. J. Lyon, "Changes in soil microbial community structure with tillage under long-term wheat-fallow management," Soil Biology and Biochemistry, vol. 32, no. 10, pp. 1419-1430, 2000.

[37] M. Ekenler and M. A. Tabatabai, "Responses of phosphatases and arylsulfatase in soils to liming and tillage systems," Journal of Plant Nutrition and Soil Science, vol. 166, no. 3, pp. 281-290, 2003.

[38] R. Lal, "Soil carbon sequestration impacts on global climate change and food security," Science, vol. 304, no. 5677, pp. 1623-1627, 2004.

[39] R. P. Dick, D. P. Breakwell, and R. F. Turco, "Soil enzyme activities and biodiversity measurements as integrative microbiological indicators," in Methods for Assessing Soil Quality, J. W. Doran and A. J. Jones, Eds., pp. 247-271, Soil Science Society of America, Madison,Wis, USA, 1996.

[40] C. E. Pankhurst, C. A. Kirkby, B. G. Hawke, and B. D. Harch, "Impact of a change in tillage and crop residue management practice on soil chemical and microbiological properties in a cereal-producing red duplex soil in NSW, Australia," Biology and Fertility of Soils, vol. 35, no. 3, pp. 189-196, 2002.

[41] S. D. Frey, E. T. Elliott, and K. Paustian, "Bacterial and fungal abundance and biomass in conventional and no-tillage agroecosystems along two climatic gradients," Soil Biology and Biochemistry, vol. 31, no. 4, pp. 573-585, 1999.

[42] P. W. Ramsey, M. C. Rillig, K. P. Feris, W. E. Holben, and J. E. Gannon, "Choice of methods for soil microbial community analysis: PLFA maximizes power compared to CLPP and PCRbased approaches," Pedobiologia, vol. 50, no. 3, pp. 275-280, 2006.

[43] R. S. Peixoto, H. L. C. Coutinho, B. Madari et al., "Soil aggregation and bacterial community structure as affected by tillage and cover cropping in the Brazilian Cerrados," Soil and Tillage Research, vol. 90, no. 1-2, pp. 16-28, 2006.

[44] N. C. Prevost-Boure, P. A. Maron, L. Ranjard et al., "Seasonal dynamics of the bacterial community in forest soils under different quantities of leaf litter," Applied Soil Ecology, vol. 47, no. 1, pp. 14-23, 2011.

[45] L. Ranjard, F. Poly, J. C. Lata, C. Mougel, J. Thioulouse, and S. Nazaret, "Characterization of bacterial and fungal soil communities by automated ribosomal intergenic spacer analysis fingerprints: biological and methodological variability," Applied and Environmental Microbiology, vol. 67, no. 10, pp. 4479-4487, 2001.

[46] R. Zornoza, C. Guerrero, J. Mataix-Solera, K. M. Scow, V. Arcenegui, and J. Mataix-Beneyto, "Changes in soil microbial community structure following the abandonment of agricultural terraces in mountainous areas of Eastern Spain," Applied Soil Ecology, vol. 42, no. 3, pp. 315-323, 2009.

[47] C. L. Lauber, M. S. Strickland, M. A. Bradford, and N. Fierer, "The influence of soil properties on the structure of bacterial and fungal communities across land-use types," Soil Biology and Biochemistry, vol. 40, no. 9, pp. 2407-2415, 2008.

[48] R. H. Findlay, "Determination of microbial community structure using phospholipid fatty acid profiles," in Molecular Microbial Ecology Manual, G. A. Kowalchuk II, Ed., pp. 9831004, Kluwer Academic Publishers, Dordrecht, The Netherlands, 2004.

[49] E. A. Paul and F. E. Clark, Soil Microbiology and Biochemistry, Academic Press, San Diego, Calif, USA, 1996. 

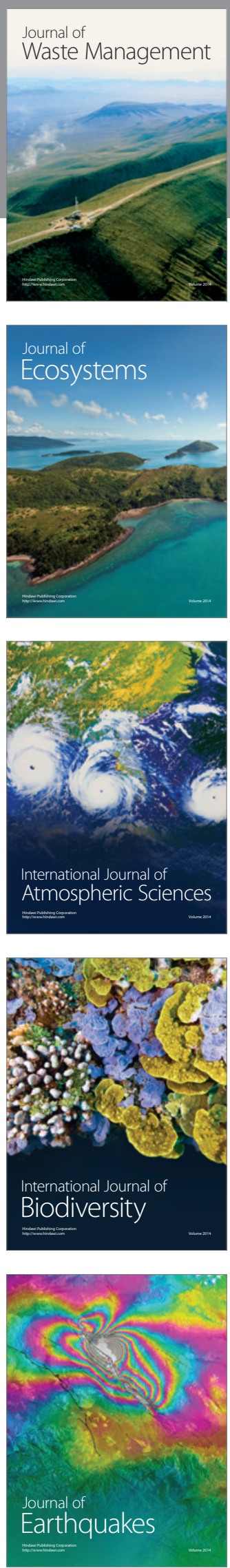
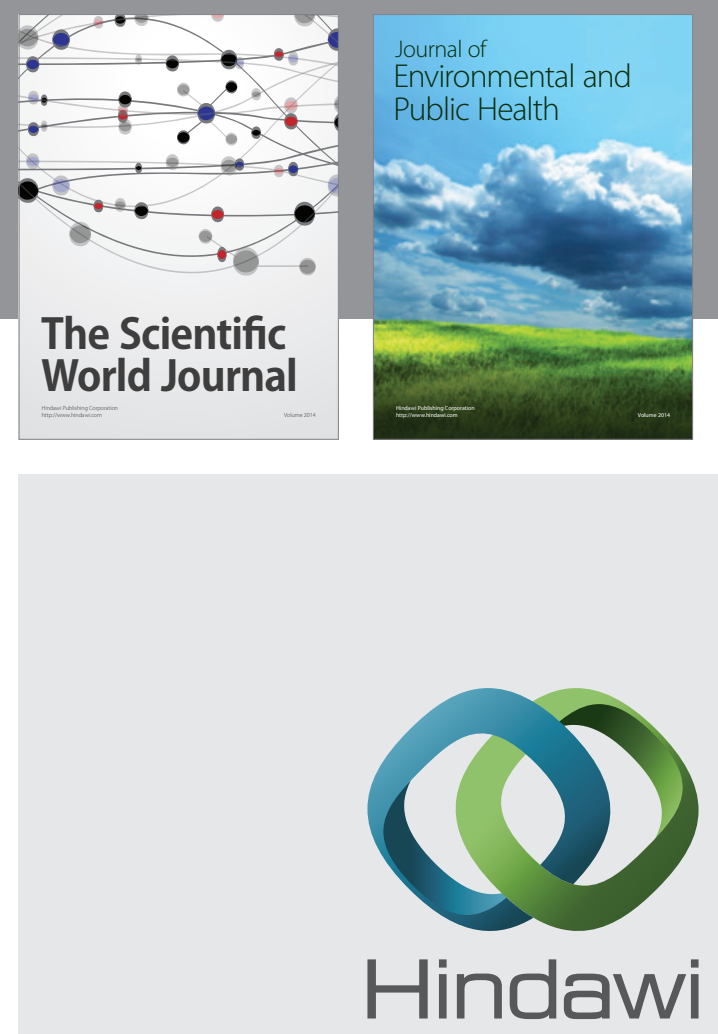

Submit your manuscripts at

http://www.hindawi.com
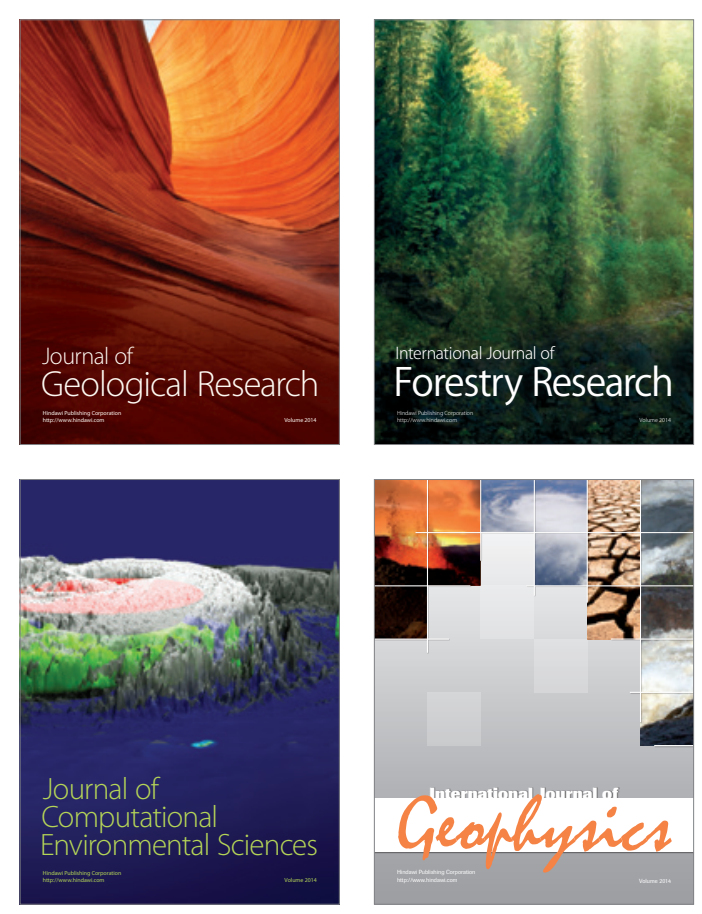
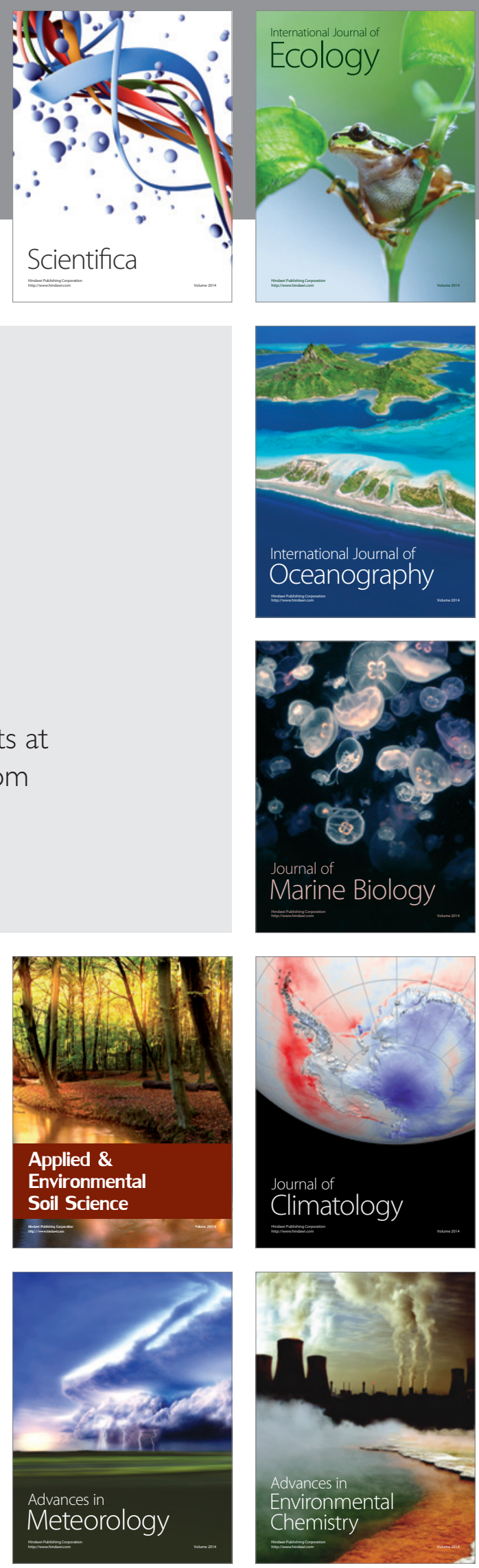